\title{
Wind-driven ventilation improvement with plan typology alteration: a CFD case study of traditional Turkish architecture
}

\begin{abstract}
Aligned with achieving the goal of net-zero buildings, the role of implementation of energysaving techniques in minimizing the energy demands are found to be more vital than at any time. As practical and economic options, passive strategies in ventilation developed over thousands of years have shown a great potential for the reduction of dwellings' energy demand, which is often underestimated in modern building construction. In particular, as a cost effective passive strategy, wind-driven ventilation via windows has a huge potential in enhancement of indoor air quality (IAQ) of buildings while simultaneously reducing their cooling load.

This study aims to investigate the functionality and applicability of a common historical Turkish architectural element called "Cumba" to improve the wind-driven ventilation in the modern buildings. A case study building with common plan archetype and parameters was firstly defined as a result of a survey over 111 different existing traditional samples across Turkey. Buildings with and without Cumbas were compared in different scenarios by development a validated CFD microclimate model. The results of simulations clearly demonstrate that Cumba can enhance the room's ventilation rate more than two times. It was also found that a smart window opening strategy can help to increase the mean ventilation rate by $276 \%$. Moreover, the room's mean air velocity and ventilation rate could be also adjusted to a broad range of values with the existence of Cumba. Thus, this study presents important findings about importance of plan typology in the effectiveness of the wind-driven ventilation strategies in modern dwellings.
\end{abstract}

Keywords: Wind-driven; ventilation; Traditional; Turkish architecture; Cumba; Computational fluid dynamics (CFD);

\section{Nomenclature}

\begin{tabular}{|c|c|c|c|}
\hline$Q$ & Volumetric airflow rate $\left(\mathrm{m}^{3} / \mathrm{s}\right)$ & $p_{k}$ & Shear production of turbulence $\left(\mathrm{kg} \mathrm{m}^{-1} \mathrm{~s}^{-3}\right)$ \\
\hline$C_{w}$ & Opening effectiveness (-) & $U, V, W$ & $\mathrm{x}-, \mathrm{y}$ - and z-component of velocity $\left(\mathrm{m} \mathrm{s}^{-1}\right)$ \\
\hline$A$ & Cross-sectional opening area $\left(\mathrm{m}^{2}\right)$ & $U_{0}$ & Free stream velocity $\left(\mathrm{m} \mathrm{s}^{-1}\right)$ \\
\hline$C_{d}$ & Discharge coefficient (-) & $X, Y, Z$ & Cartesian coordinates $(\mathrm{m})$ \\
\hline$\rho$ & Density of the fluid $\left(\mathrm{kg} \mathrm{m}^{-3}\right)$ & $k$ & Turbulence kinetic energy $\left(\mathrm{m}^{-2} \mathrm{~s}^{-2}\right)$ \\
\hline$C_{p}$ & Mean pressure coefficient(-) & $\Delta$ & Difference (-) \\
\hline$C_{\mu R N G}$ & RNG k- $\varepsilon$ turbulence model constant (-) & $\varepsilon$ & Turbulence dissipation rate $\left(\mathrm{m}^{-2} \mathrm{~s}^{-3}\right)$ \\
\hline$C_{\varepsilon 1 R N G}$ & RNG k- $\varepsilon$ turbulence model coefficient (-) & $\mu$ & Viscosity $\left(\mathrm{kg} \mathrm{m}^{-1} \mathrm{~s}^{-1}\right)$ \\
\hline$C_{\varepsilon 2 R N G}$ & RNG k- $\varepsilon$ turbulence model constant (-) & $\sigma_{k R N G}$ & RNG k- $\varepsilon$ turbulence model constant (-) \\
\hline$P$ & Pressure $\left(\mathrm{kg} \mathrm{m}^{-1} \mathrm{~s}^{-2}\right)$ & $\sigma_{\varepsilon R N G}$ & RNG k- $\varepsilon$ turbulence model constant (-) \\
\hline$P_{0}$ & Free stream static pressure $\left(\mathrm{kg} \mathrm{m}^{-1} \mathrm{~s}^{-2}\right)$ & & \\
\hline
\end{tabular}

\section{Introduction}

The average global temperature anomaly has risen by $0.68^{\circ} \mathrm{C}$ since the $1880 \mathrm{~s}$ (NASA/GCC, 2016), and with current rates of global warming the mean global surface temperature is expected to increase by $3-5^{\circ} \mathrm{C}$ in the long term compared to its preindustrial level (IPPC/CC, 2014). The side effects of this temperature elevation are identified as lower thermal comfort and higher energy demand in urban areas and buildings worldwide.

Thermal comfort in indoor spaces is among the primary factors that impact on human health, as humans spend approximately $90 \%$ of their daily time indoors (Lai, et al., 2004; Vardoulakis, et al., 2015), which can increase to $100 \%$ for elderly dwellers and young children, who are among the most vulnerable groups to the severe heat (Torfs, et al., 2008). Recent studies show that numerous heatrelated mortalities occur in unequipped houses during unusual warm episodes, particularly in heat 
waves, which cause more human mortality compared with other climatic-related natural catastrophes (Wilhelmi, et al., 2004). In Europe, approximately 50,000 people died during a heat wave in August 2003 (Mirzaei \& Haghighat, 2010).

Future buildings should be able to cope with the new climatic conditions to not only enhance the level of thermal comfort, but to also significantly reduce their energy demand (and stop contributing to the problem of global warming). Currently, residential buildings are responsible for $40 \%$ of the global energy demand, and $82 \%$ of this energy is produced by non-renewable sources (WEC/WERS, 2013). The race for global economic growth and the rapidly increasing global population are projected to raise primary energy demand by $61 \%$ by 2050 (WEC/WES-2050, 2013). Therefore, there is an urgent obligation for the construction industry to devise and implement policies, codes and technology to significantly reduce its energy demand. Promoting energy efficient and environmental friendly dwellings with advanced passive technologies is recognized as a potential and viable solution in attenuating energy demand (Samuel \& Nagendra, 2013), particularly in major emerging economies such as China, India, Brazil and Turkey.

As a cost effective passive strategy, wind-driven ventilation has a huge potential to improve indoor air quality (IAQ) in terms of air replacement and to reduce the cooling load of buildings (McQuiston, Parker, \& Spitler, 2005). For example, studies by Lee et al. (2013) and Mochida et al. (2006) emphasise on the significant effect of wind flow patterns around the building on wind-driven natural ventilation through windows. In another study, (Heiselberg, Svidt, \& Nielsen, 2001) investigated the influence of different window configurations and opening positions on natural ventilation efficiency, indoor air quality and thermal comfort. However, these studies noted the major limitation of wind-driven natural ventilation, which are the unpredictable variations of wind in terms of direction and speed (Chu \& Chiang, 2013).

Traditional dwellings developed through thousands of years inherently utilized various passive strategies, including wind-driven technologies, to satisfy the thermal comfort of their inhabitants while preserving precious and limited sources of energy. Current investigations acknowledge the functionality of many of these traditional designs in providing thermal comfort while being energy efficient (Cantin et al., 2010; Dili, Naseer, \& Varghese, 2011). For example, a field study of 11 buildings in France by Cantin et al. (2010) has shown the traditional buildings built before the 1930s are considerably more energy efficient compared to the average modern dwelling built in 2004. A similar observation was reported by (Dili, Naseer, \& Varghese, 2011) based on an evaluation of buildings built after 1985 and traditional buildings (about three hundred years old) in Kerala, India.

There have been numerous highly effective natural ventilation techniques in architectural history. For example, wind-catchers (Bâdgir) have been used as an evaporative ventilation and cooling system in Persian architecture for past three thousand years. In recent years, modern wind-catchers have been developed and adapted in different climates (Saadatian, Haw, Sopian, \& Sulaiman, 2012). Such studies clearly highlight on the potential of wind-driven ventilation to be adapted and integrated into the current modern developments.

Cumbas (Fig. 1) are a popular traditional architectural element from the Ottoman period that remains widespread in Turkish dwellings. However, despite the widespread implementation of such archetypes, scientific study has barely considered their functionality. This study thus aims to investigate the role of Cumbas in wind-driven ventilation in low-rise dwellings. For this purpose, a 
preliminary study among 111 different traditional Turkish houses was first conducted to identify the features of the typical Cumba and its plan typology, as a base case scenario. A 3D microclimate CFD (Computational Fluid Dynamics) model of the selected building was then developed to assess the potential of wind-driven ventilation using 24 different scenarios, including various wind directions, velocities and window opening configurations.

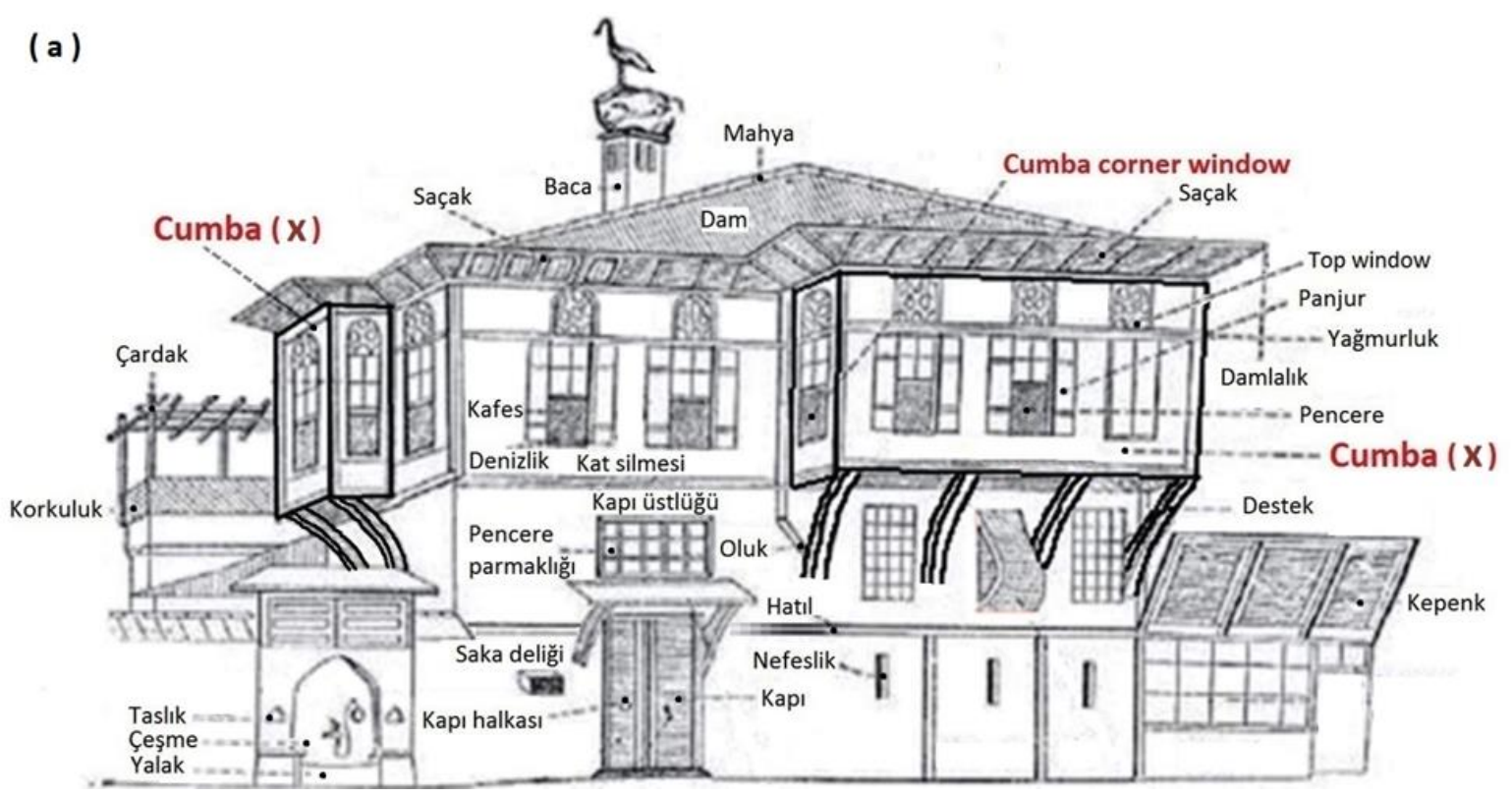

(b)

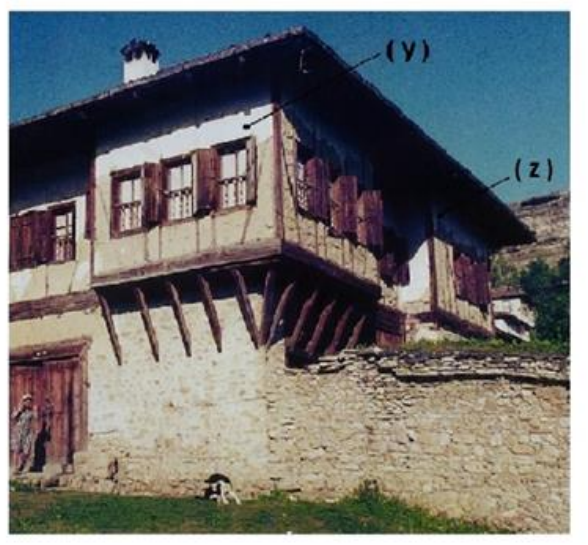

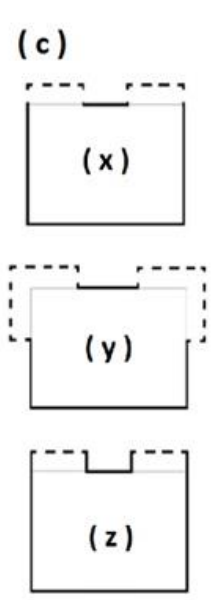

(d)

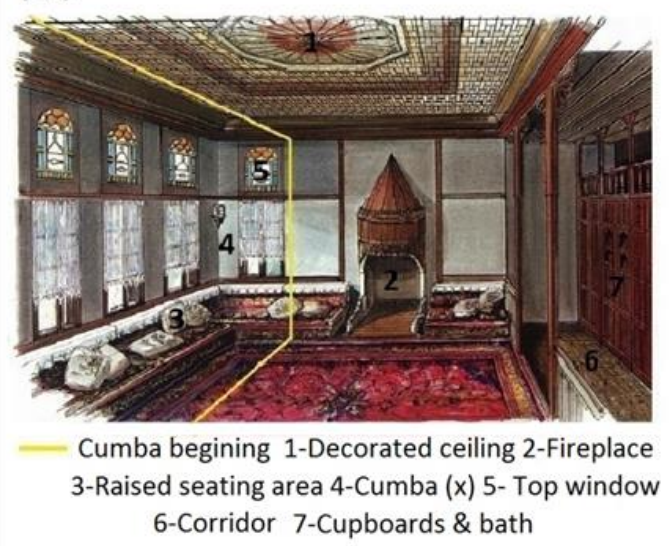

Fig. Error! No text of specified style in document. (a) Cumba and traditional Turkish house components (Arseven, 1983), (b) traditional Turkish house (Kucukerman, 2007) (c) the most common types of Cumba (xthree-sided Cumba, $y$ - four-sided Cumba, and z- one-sided Cumba), (d) typical traditional Turkish interior room and Cumba (Kucukerman, 2007)

\section{Survey of existing Turkish houses}

Traditional Turkish architecture was drastically developed during the Ottoman period. As shown in Fig. 1, the Cumba can be simplified as an extension of rooms in the first or upper floors, covered by windows on one to four different facades (Fig. 1C). Traditional Turkish houses are widespread in Anatolia, Rumelia and the Balkans (Küçükerman, 2007; Eldem, 1984). Although there 
are slight differences in building plan characteristics associated with local materials and climates, all traditional dwellings share the fundamental characteristics of Turkish domestic architecture (Essad, 1909), which ultimately originate in paleo-Turkic nomadic dwellings, whereby family tents were pitched around a common hall area (similar to Sofa), with inter-linked independence of each living unit, with a flexibility typology in the floor plan. The typical configurations of houses mean that is easy to estimate the dwelling layout from a view of the exterior based on patterns of building development from the interior to the exterior borders (See Fig. 1b).

A Turkish house plan consists of rooms aligned around the Sofa (Günay, 1998), a unique hall used as the main area for the social activities that provides access to the rooms. Moreover, the Sofa is the main distinctive element that creates dwellings characteristics. In other words, the room plan typology shows no significant distinctions, but room-Sofa connections can significantly vary from building to building. The nature and use of this common hall between individual rooms is a defining characteristic of the traditional Turkish dwelling, with the result that it generally has no corridors, in contrast to many European houses.

\begin{tabular}{lll}
\hline & Plan typology categorization \\
\hline
\end{tabular}

Fig. 2 Plan typology of 111 studied buildings

Cumba characteristics vary with the building size and location, room-Sofa connection, room size, window size, window configurations and construction materials (Eldem, 1984). Therefore, a preliminary and comprehensive case study in accordance to the recognised parameters was conducted on 111 different existing building in 20 cities of Turkey to identify the most common layout, typology and archetype of traditional Turkish houses. As the result, Turkish house typologies were placed under five different main categories, as illustrated in Fig. 2.

Also, Fig. 3 shows the location of the selected sample buildings, which were mainly built after the $18^{\text {th }}$ century, with the vast majority being located in western and south-western Turkey. It can be seen that the majority of these buildings are located in Istanbul (37\%) and Antalya (15\%). 


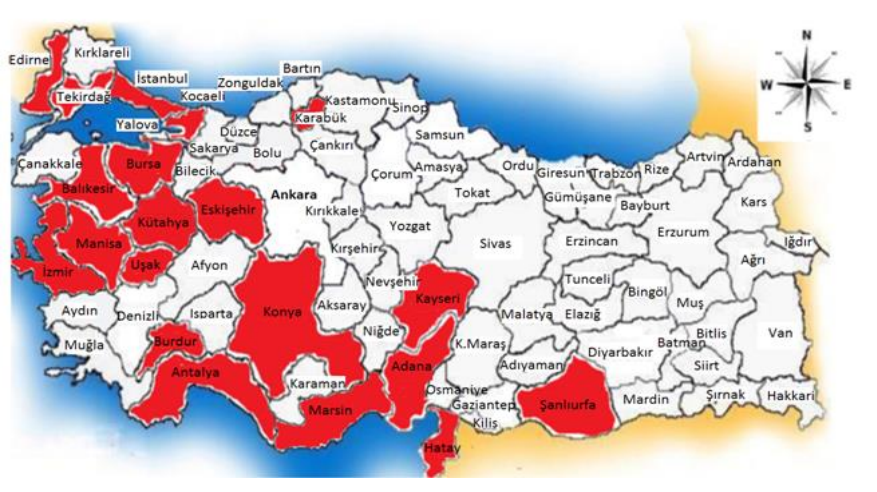

\begin{tabular}{cccc} 
City & $\begin{array}{c}\text { Sample } \\
\text { house } \\
\text { number }\end{array}$ & City & $\begin{array}{c}\text { Sample } \\
\text { house } \\
\text { number }\end{array}$ \\
\hline İstanbul & 41 & Kayseri & 2 \\
Antalya & 17 & Hatay & 2 \\
Kocaeli & 8 & Konya & 2 \\
Manisa & 7 & Urfa & 1 \\
Bursa & 6 & Edirne & 1 \\
İmir & 5 & Burdur & 1 \\
Karabük & 5 & Mersin & 1 \\
Kütahya & 3 & Uşak & 1 \\
Tekirdağ & 3 & Adana & 1 \\
Eskişehir & 3 & Balıkesir & 1
\end{tabular}

Fig. 3 Location and number of the studied traditional buildings in Turkey

Table 1 The overall characteristics of 111 sample buildings

\begin{tabular}{|c|c|c|c|c|c|c|c|c|}
\hline & \multirow[b]{2}{*}{ Minimum } & \multirow[b]{2}{*}{ Maximum } & \multirow[b]{2}{*}{ Average } & \multicolumn{5}{|c|}{ Number and area of room } \\
\hline & & & & $0-10\left(m^{2}\right)$ & $11-20\left(\mathrm{~m}^{2}\right)$ & $21-30\left(m^{2}\right)$ & $31-40\left(\mathrm{~m}^{2}\right)$ & $\begin{array}{l}>41 \\
\left(\mathrm{~m}^{2}\right)\end{array}$ \\
\hline Small Room Area $\left(\mathrm{m}^{2}\right)$ & 6.25 & 40 & 18 & 11 & 64 & 36 & 2 & \\
\hline Main Room Area $\left(\mathrm{m}^{2}\right)$ & 15 & 56 & 28.3 & & 19 & 56 & 23 & 13 \\
\hline \multirow{3}{*}{ Number of Rooms } & \multirow{2}{*}{2} & \multirow{2}{*}{14} & \multirow{2}{*}{4} & $(2-4)$ & (5-7) & $(8-10)$ & $(11-13)$ & (14) \\
\hline & & & & 75 & 28 & 6 & 1 & 1 \\
\hline & & & & \multicolumn{5}{|c|}{ Number of windows } \\
\hline \multirow{2}{*}{ Window Width (m) } & & & & $0.6(\mathrm{~m})$ & $0.7(\mathrm{~m})$ & $0.8(\mathrm{~m})$ & $0.9(\mathrm{~m})$ & $1(\mathrm{~m})$ \\
\hline & 0.6 & 1 & 0.8 & 6 & 33 & 52 & 19 & 14 \\
\hline
\end{tabular}

The most common characteristics of the selected sample buildings were analysed and summarized in Table 1. It can be seen that the majority of the buildings have four rooms. The area of the main and smallest rooms varies between $11-20 \mathrm{~m}^{2}$ and $21-30 \mathrm{~m}^{2}$, respectively. Their windows' widths range from $0.6 \mathrm{~m}$ to $1 \mathrm{~m}$, with the most common being about $0.8 \mathrm{~m}$ (Table 1 ). $82 \%$ of the sample buildings contain an average of two Cumbas in their design, and about $75.8 \%$ of the Cumba typologies are three-sided (Fig. 1C). It was also observed that $30 \%$ of Cumbas are orientated toward the north. In general, Cumbas are oriented toward the cardinal directions, as can be seen in Fig. 2. It is important to underline that the sample buildings are located in 20 different cities, thus they are oriented against various wind directions according to their local and regional climatic conditions.

The mean characteristics of the conducted survey were then used to form a case study to represent the layout and characteristic of a traditional Turkish houses and to further investigate the potential of wind-driven ventilation in such buildings. The case study building therefore can be assumed as a two-storey building located in Istanbul. The original and modified layouts of this building are illustrated in Fig. 4. The ground and first floor are used as storage and living areas, respectively. The first floor has four rooms and a Sofa, while the areas of the smallest and main rooms (NW-SW and $\mathrm{NE}$ ) are $16 \mathrm{~m}^{2}$ and $30 \mathrm{~m}^{2}$, respectively. Moreover, with a minor modification the studied building has three-sided Cumba at the northwest room with windows of $0.8 \mathrm{~m}$ width. In the original plan, the northwestern room and Sofa have a one-sided Cumba (Fig. 1C), and the north-eastern room has a four-sided one (Fig. 1c).

As illustrated in Fig. 4b, the building layout was modified and simplified to prepare a microclimate CFD model with and without Cumba. All investigated scenarios in this study are 
compared with layout in which northwest room is modified from a one-sided to a three-sided Cumba (Fig. 4b), which was found to be a more common combination. Thus the north-west Cumba was modified by adding two $0.8 \mathrm{~m}$-wide windows on the eastern and western façades. The wall between the northeast and northwest rooms was extended, as indicated by dots in Fig. 4b. The roof shape was also assumed to be flat, in order to simplify the construction of 3D mesh of the microclimate CFD model (Fig. 4b). Moreover, the southern rooms were assumed to be aligned with the Sofa to further simplify the case study model (Fig. $4 a-b)$. The area of the northwest room was kept the same $\left(16 \mathrm{~m}^{2}\right)$ in all scenarios.

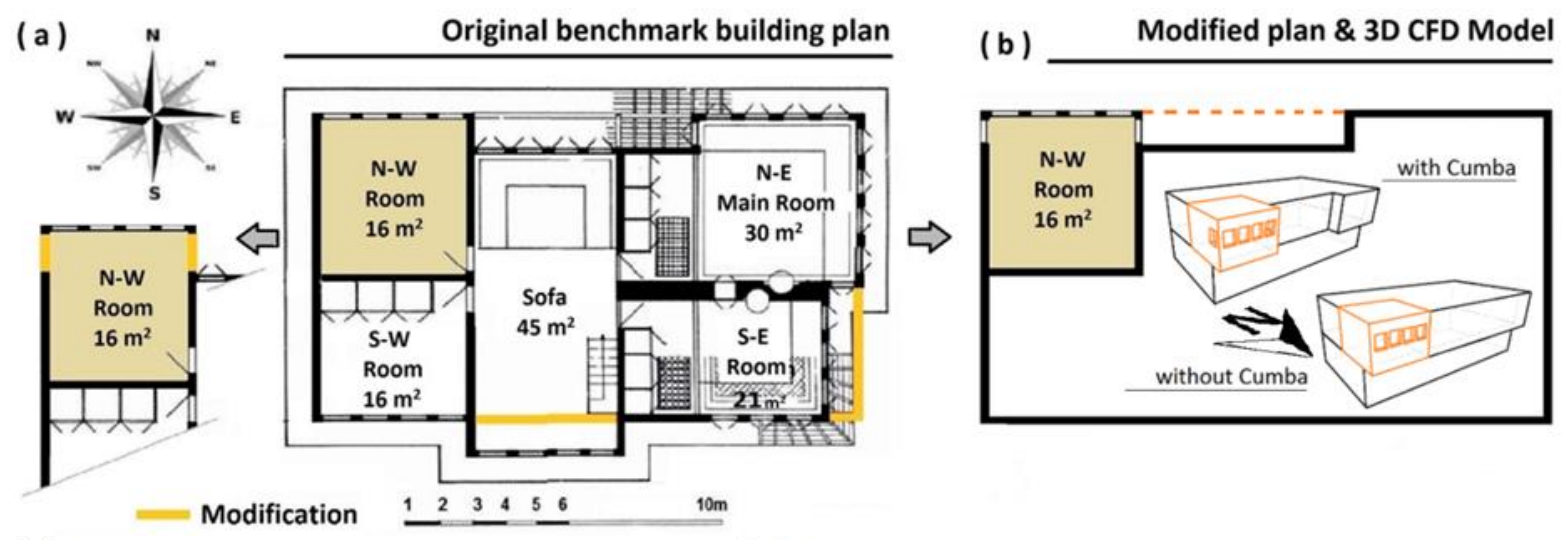

(c)

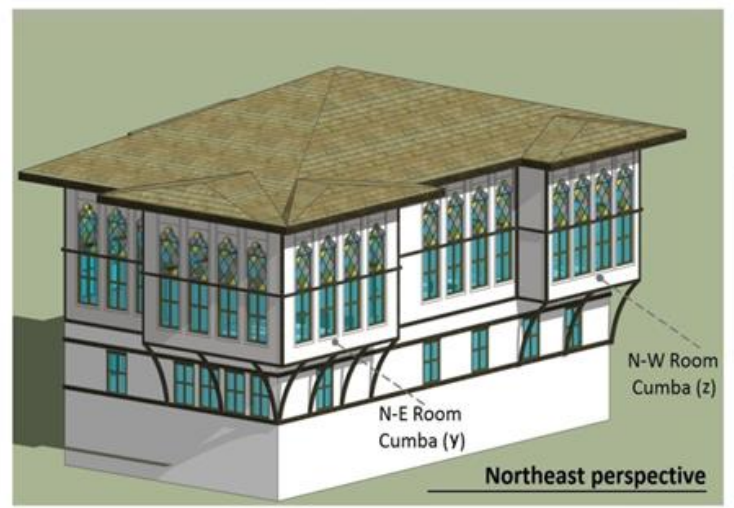

(d)

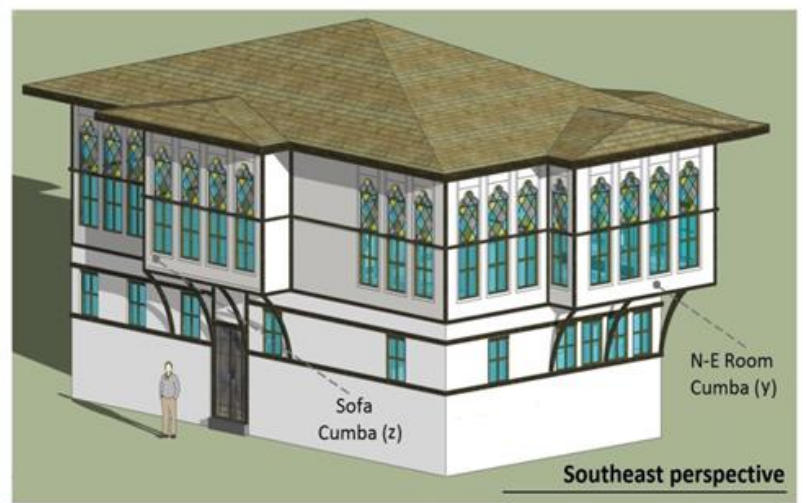

Fig. 4 (a) Original layout (Talya, 2007) and Cumba modification of the selected building, (b) Simplified benchmark building layout with and without Cumba, (c and d) the studied building

\section{Methodology}

Computational fluid dynamics (CFD) technology is a powerful tool to understand of the impact of wind in natural ventilation (Mirzaei \& Haghighat, 2010). Table 2 summarizes recent CFD works based on the utilized turbulence model and assessment indices. Evola \& Popov, (2006) examined the wind-driven natural ventilation of a cubic building using standard $k-\varepsilon$ and RNG turbulence models, while Gebremedhin \& Wu, (2003) assessed flow field in a multiple-occupancy ventilated space using a microclimate CFD model. Moreover, Teppner et al., (2014) assessed the air change rate (AHC) of a series of open and tilted windows in a naturally ventilated isolated residential building. Bangalee, Lin, \& Miau, (2012) compared single-sided and cross wind-driven ventilations within an isolated one-storey building using $\mathrm{k}-\varepsilon$ turbulence model, and Mochida et al., (2006) studied cross-ventilation cooling effect around a building by development of a microclimate model. Kobayashi et al., (2010) used applied Reynolds Stress Model (RSM) to assess wind-driven ventilation flow through different opening sizes of a single room with comparison of the velocity and pressure differences. Furthermore, Chu \& Chiang, 
(2014) investigated wind-driven ventilation of isolated long buildings with internal obstacles using Large Eddy Simulation (LES). The majority of these studies utilized air velocity and ventilation rates as indices to assess the performance of the wind-driven ventilation, therefore these indices were also utilized in this study to evaluate the contribution of Cumbas to the improvement of wind-driven ventilation.

Table 2 Recent CFD wind-driven natural ventilation studies

\begin{tabular}{lcclcc}
\multicolumn{1}{c}{ Reference } & Assessment & $\begin{array}{c}\text { Turbulence } \\
\text { Model }\end{array}$ & \multicolumn{1}{c}{ Reference } & Assessment & $\begin{array}{c}\text { Turbulence } \\
\text { Model }\end{array}$ \\
\hline Chu \& Chiang (2013) & AV - PR - VR & LES (SST) & Kobayashi at al.(2010) & AV - PR & RSM \\
Norton et al. (2009) & VR - ACH- TD & SK- $-\varepsilon$ & Ai \& Mak (2014) & AV - PL & RNG K- $-\varepsilon$ \\
Bangalee et al. (2012) & AV- PR & RNG K- $-\varepsilon$ & Perén, et al. (2015) & VFR - AV- PR & SST \\
Chu \&Chiang (2014) & AV - PR & LES (SST) & Teppner at al. (2014) & AV-ACH- PR & SK- $\varepsilon$ \\
Mochida at al. (2006) & TD - ACH - AV & DKE & Evola \& Popov (2006) & AV- PR-VR & SK- - -RNG
\end{tabular}

SK- $\varepsilon=$ Standard $k-\varepsilon$ model - RANS $=$ Reynolds-averaged Navier-Stokes - RNG $=$ Renormalization Group k- $\varepsilon$ model - DKE $=$ Durbin $\mathrm{k}-\boldsymbol{\varepsilon}$ model $-\mathbf{R S M}=$ Reynolds stress model $-\mathbf{S S T}=$ Shear-stress transport $\mathrm{k}-\boldsymbol{\omega}$ model $-\mathbf{A V}=$ Air velocity $-\mathbf{V R}=$ Ventilation rates $-\mathbf{A C H}=$ Air exchange rate $-\mathbf{T D}=$ Temperature difference $-\mathbf{P R}=$ Pressure difference $-\mathbf{P L}=$ Pollution - VFR $=$ Volumetric flow rate

\subsection{Climatic conditions}

As summarised in Table 3, the wind-driven ventilation effect of Cumbas was studied under three main conditions in 24 scenarios, including five different wind directions from north, northwest, northeast, west and east; four different wind velocities of $1.7 \mathrm{~m} / \mathrm{s}, 3.3 \mathrm{~m} / \mathrm{s}, 4.7 \mathrm{~m} / \mathrm{s}$, and $5.5 \mathrm{~m} / \mathrm{s}$ (S1S20); and four different window opening configuration scenarios (S21-S24). Wind velocities and directions were inserted to the model according to the monthly average statistics of Istanbul for the last 18 years. The recorded monthly wind velocity shows a minimum of $1.7 \mathrm{~m} / \mathrm{s}$ (IUG-MI, 2015), a maximum of $5.5 \mathrm{~m} / \mathrm{s}$ and an average of $4.7 \mathrm{~m} / \mathrm{s}$. Moreover, $3.3 \mathrm{~m} / \mathrm{s}$ wind velocity was simulated as an additional scenario to cover a spectrum of velocities between minimum and maximum values. Similarly, the air temperature was selected according to Istanbul's annual average temperature of $14^{\circ} \mathrm{C}$ (WB, 2016).

Table 3 Summary of case study scenarios for 48 CFD simulations

\begin{tabular}{|c|c|c|c|c|c|c|}
\hline \multirow[t]{2}{*}{ Scenario } & & \multicolumn{5}{|c|}{ With Cumba and without Cumba } \\
\hline & & North & East & West & Northeast & Northwest \\
\hline \multirow{4}{*}{ Wind velocity $(\mathrm{m} / \mathrm{s})$} & 1.7 & S1 & S2 & S3 & S4 & S5 \\
\hline & 3.3 & S6 & S7 & S8 & S9 & S10 \\
\hline & 4.7 & S11 & S12 & S13 & S14 & S15 \\
\hline & 5.5 & S16 & S17 & S18 & S19 & S20 \\
\hline \multicolumn{2}{|c|}{ Window opening scenarios } & \multicolumn{5}{|c|}{$\begin{array}{l}\text { Under Northward prevailing wind and average } \\
\text { wind velocity of } 4.7 \mathrm{~m} / \mathrm{s}\end{array}$} \\
\hline \multirow{4}{*}{ Opening configuration } & S21 & \multicolumn{5}{|c|}{ W1 - W2 - W3 - W4 - W5 - W6 } \\
\hline & S22 & \multicolumn{5}{|c|}{ W2 - W3 - W4 - W5 } \\
\hline & S23 & \multicolumn{5}{|c|}{ W2 - W3 - W4 - W5 - W6 } \\
\hline & S24 & \multicolumn{5}{|c|}{ W1 - W2 - W3 - W4 - W5 } \\
\hline
\end{tabular}

\subsection{Microclimate CFD model}

As shown in Fig. $5 \mathrm{a}$, the CFD model is a two-storey building with a storey height of $3 \mathrm{~m}(6 \mathrm{~m}$ in total). The ground floor was assumed to be $17 \mathrm{~m} \times 8.5 \mathrm{~m} \times 3 \mathrm{~m}$ (length $\mathrm{x}$ width $\mathrm{x}$ height), and the first floor had same dimensions as the ground floor, with $1 \mathrm{~m}$ extension of two Cumbas on the north (Fig. $5 a)$. Mean indoor air speed and ventilation rate were only simulated in the modified northwest room 
with a three-sided Cumba; the northwest room door was assumed to be closed and the other rooms and the Sofa were not included in the simulations. As shown in Fig. 5b, the dimension of the northwest room is $4.5 \mathrm{~m} \times 4.5 \mathrm{~m} \times 3 \mathrm{~m}$ (length $\mathrm{x}$ width $\mathrm{x}$ height), including $0.25 \mathrm{~m}$ wall thickness. The north façade of the integrated Cumba has four $0.8 \mathrm{~m} \times 1 \mathrm{~m}$ (width $\times$ height) windows, whereas the east and west façades have only one window each. All windows are located at $4.5 \mathrm{~m}$ height from the floor, and are assumed to be opened in simulations scenarios of S1 through S21.
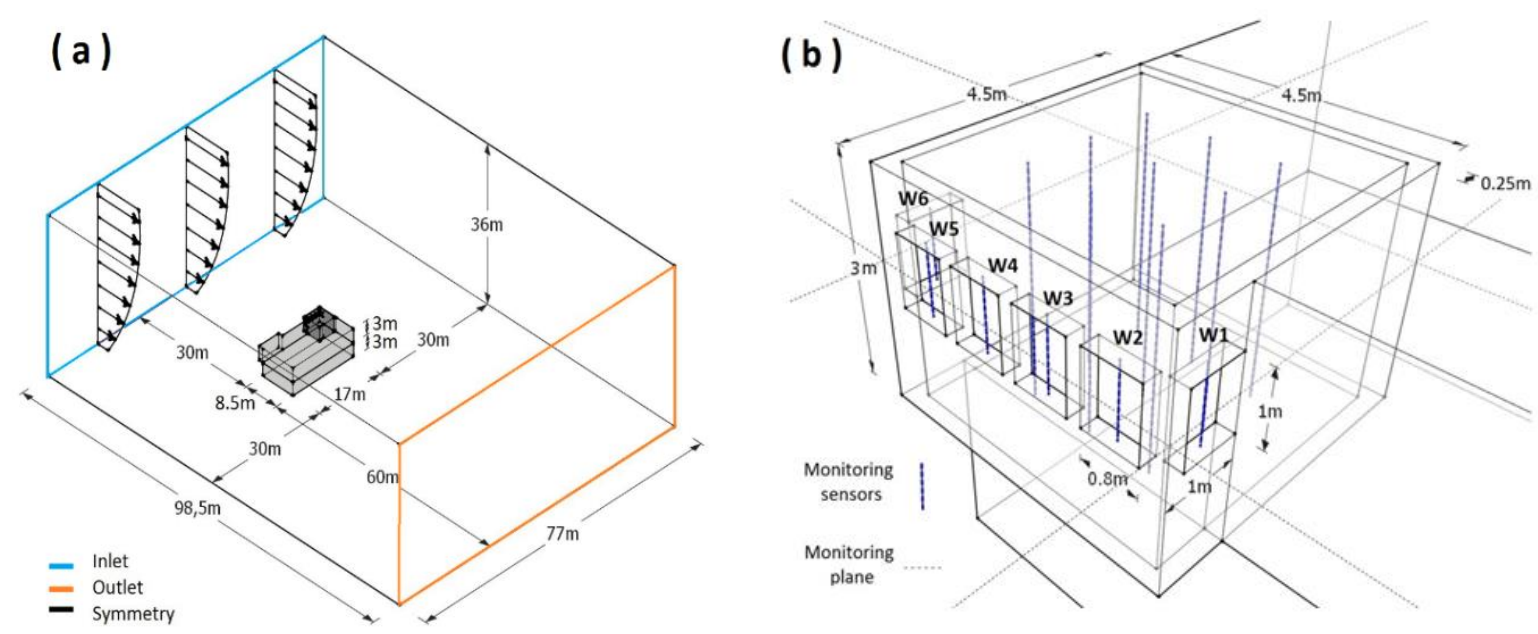

Fig. 5. (a) (a) Microclimate CFD model of the building with Cumba, (b) locations of the monitored velocities

\subsubsection{Grid Generation}

A microclimate domain around the building was first generated to ensure the accurate representation of the approaching wind. Recommended microclimate domain and boundary conditions were broadly mentioned in literature and CFD best practice guidelines (Franke, et al, 2007; Mochida et al., 2008). Considering these guidelines and computational constraints, the domain dimensions were set to be $98.5 \mathrm{~m} \times 77 \mathrm{~m} \times 36 \mathrm{~m}$, as depicted in Fig. 5a. Microclimate CFD domain size was also expanded according to the five different wind directions to ensure sufficient distance between boundaries and the isolated building. The inflow, outflow and symmetry boundary conditions were respectively associated to the inlet, outlet and lateral walls of the study domain to replicate appropriate boundary conditions (Mirzaei et al., 2010 and 2012). Moreover, the boundary surfaces of the Turkish house model were defined as walls, with no slip condition for the surfaces.

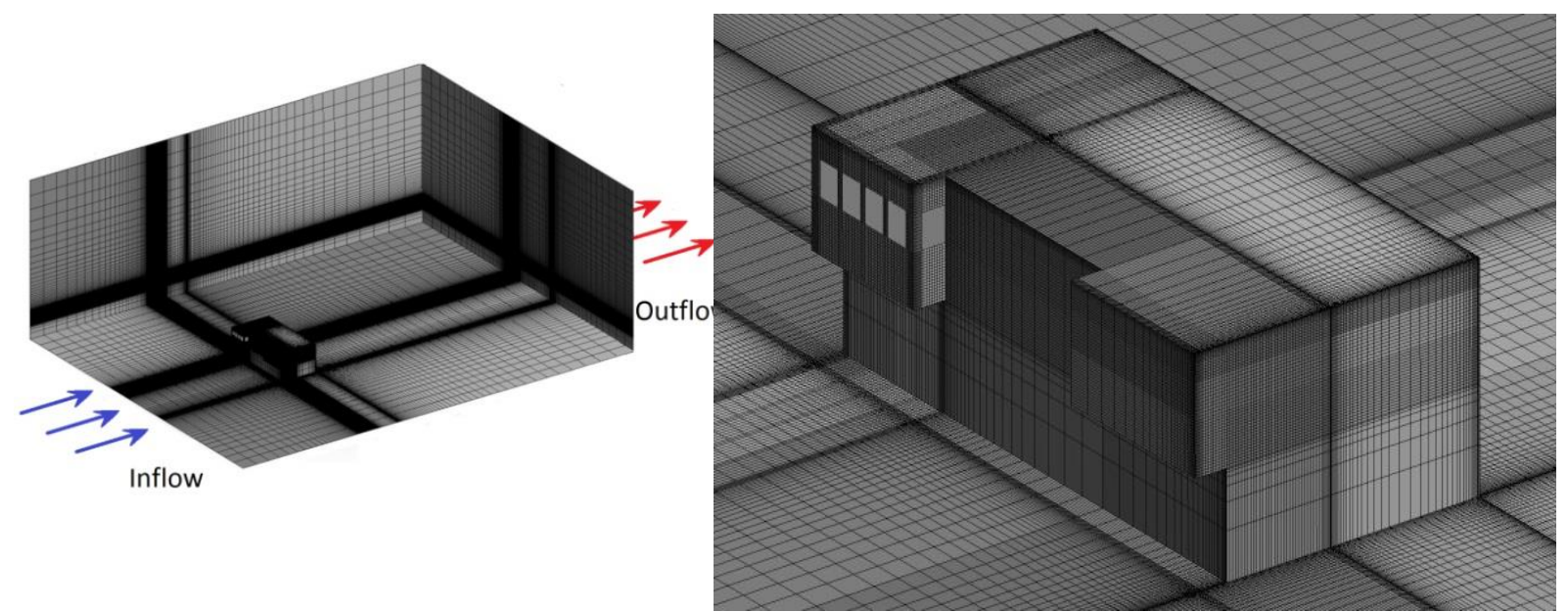

Fig. 6 Generated grid around Cumba 
After several refinements of the CFD domain grid, a mesh consisting of 2.8 million structured non-uniform cells was generated to satisfy the mesh independency of the grid. The accuracy and solution convergence of the simulations was also calibrated in accordance with the recommended guidelines (Horan \& Finn, 2008). As can be seen in Fig. 6, grid resolutions were arranged to be denser in the regions where the large flow gradients are expected to capture the boundary layer effect of the inner layer (Mirzaei \& Carmeliet, 2013). Inflated cells were also used to obtain higher resolution around the building and external boundaries.

\subsubsection{Governing equations}

Reynolds-Averaged Navier-Stokes (RANS) method was utilized to solve the governing air transport equations. In addition, the airflow was assumed to satisfy isothermal and incompressible conditions in the microclimate model. Re-Normalization Group (RNG) $k-\varepsilon$ was also employed as the turbulence model to assess the wind-driven ventilation contribution of the Cumba. Several studies emphasized the advantages and high reliability of RANS RNG $k-\varepsilon$ turbulence model in the application of natural and mechanical ventilation simulations (Evola \& Popov, 2006; Bangalee, Lin, \& Miau, 2012). The governing equations for continuity and momentum are as shown below:

$$
\begin{gathered}
\frac{\partial}{\partial x_{j}}\left(U_{j}\right)=0 \\
\rho U_{j} \frac{\partial}{\partial x_{j}}\left(U_{i}\right)=-\frac{\partial_{p}}{\partial x_{i}}+\frac{\partial}{\partial x_{j}}\left[\left(\mu+\mu_{T}\right) \frac{\partial U_{i}}{\partial x_{j}}\right]
\end{gathered}
$$

where $i, j=1,2,3$ and $\mu_{T}$ is turbulent viscosity, represented as:

$$
\begin{gathered}
\mu_{T}=C_{\mu R N G} \rho \frac{k^{2}}{\varepsilon} \\
\rho \frac{\partial}{\partial x_{j}}\left(U_{j} k\right)=\frac{\partial}{\partial x_{j}}\left[\left(\mu+\frac{\mu_{T}}{\sigma_{k R N G}}\right) \frac{\partial k}{\partial x_{j}}\right]+P_{k}-\rho \varepsilon \\
\rho \frac{\partial}{\partial x_{j}}\left(U_{i} \varepsilon\right)=\frac{\partial}{\partial x_{j}}\left[\left(\mu+\frac{\mu_{T}}{\sigma_{\varepsilon R N G}}\right) \frac{\partial \varepsilon}{\partial x_{j}}\right]+\frac{\varepsilon}{k}\left(C_{\varepsilon 1 R N G} P_{k}-C_{\varepsilon 2 R N G} \rho \varepsilon\right)
\end{gathered}
$$

where constant values are defined as $C_{\mu R N G}=0.085, C_{\varepsilon 2 R N G}=1.68, \sigma_{k R N G}=0.7179, \sigma_{\varepsilon R N G}=0.7179, \beta_{R N G}=$ 0.012 , thus:

$$
C_{\varepsilon 1 R N G}=1.42-\frac{\eta(4.38-\eta)}{4.38\left(1+\beta_{R N G} \eta^{3}\right)}, \quad \eta=\sqrt{\frac{P_{k}}{\rho C_{\mu R N G} \varepsilon}}
$$

\section{Validation of the microclimate model}

The results of the CFD simulation were compared with Bangalee, (2012) to validate the developed model. They simulated the airflow within an isolated room as presented in Fig. 5b with only two windows, W2 and W5, in lateral walls. The northwest room with and without Cumba was monitored in 15 different vertical lines located at the centre of windows (W1-W6) and a grid of multiple nodes with the distance of $1 \mathrm{~m} \times 1 \mathrm{~m}$ inside the studied room (see Fig. 5b). These lines were extended from the floor to ceiling, and had a $1 \mathrm{~m}$ distance from wall surfaces. In addition, vertical monitoring planes 
were assumed at windows (W1-W6) to calculate the surface integral of air velocity and pressure to capture their variations at the centre and boundary of the windows as presented in Fig. 5b.

Fig. 7 shows the air velocity comparison between the results of the microclimate CFD model and those of Bangalee (2012). It can be seen that the velocity in the studied windows is in a fair agreement with the CFD simulation conducted by Bangalee (2012); the obtained average discrepancy is about 5.9\%, which represents a similar trend as the results of Bangalee (2012) simulated at the centreline of the windows. Specifically, the mean air velocity differences for windows W5 and W2 are calculated to be $5.0 \%$ and $6.8 \%$, respectively. The validated microclimate CFD model is used in further scenarios of this study with the addition of four more windows, W1, W3, W4 and W6, to the studied room.

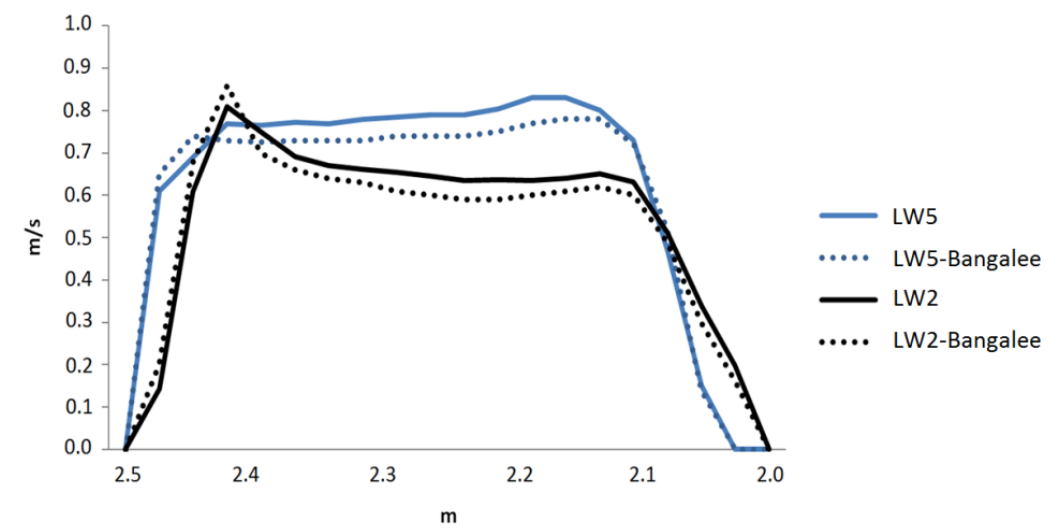

Fig. 7 Comparison of the velocity profile at the middle of windows W5 and W2 between developed microclimate CFD model and Bangalee (2012)

\section{Results and Discussion}

The CFD results indicate that Cumbas can effectively harvest wind approaching from different directions and speeds (S1-S20) to improve the mean indoor air velocity and ventilation rate of the studied room. Similarly, these indices can be significantly increased when different window opening strategies are utilized in the building with the existence of Cumbas (S21-S24).

\subsection{Influence of the wind characteristics}

\subsubsection{Indoor air velocity}

The comparison of the room mean air velocity according to different wind directions and velocities is shown in Fig. 8. The threshold of an indoor air velocity to satisfy the comfort level is also shown with a black circle in Fig. 8. This indicates that the air speeds inside the circle are assumed inadequate to satisfy occupant's comfort. On the other hand, indoor air velocities between $0.5 \mathrm{~m} / \mathrm{s}$ and $1.0 \mathrm{~m} / \mathrm{s}$ and between $1.0 \mathrm{~m} / \mathrm{s}$ and $1.7 \mathrm{~m} / \mathrm{s}$ can be respectively defined as ideal and pleasant breeze for occupants (ECOTECT, 2016). Eventually, the speed above $1.7 \mathrm{~m} / \mathrm{s}$ is defined as unpleasant.

Indoor air velocity above the comfortable range is not observed in any scenarios (S1-S20). The highest indoor air velocity is observed in scenario $S 16$ to be about $1.6 \mathrm{~m} / \mathrm{s}$ against the north wind with velocity of $\mathrm{U}=5.5 \mathrm{~m} / \mathrm{s}$. In the majority of the scenarios, indoor air velocity was observed to be below 1.0 $\mathrm{m} / \mathrm{s}$, excluding S11-S16 against the north wind. In contrast, for all non-Cumba scenarios (S1-S20), indoor air velocity is almost obtained to be below the comfortable range except for two scenarios (S15S20). 

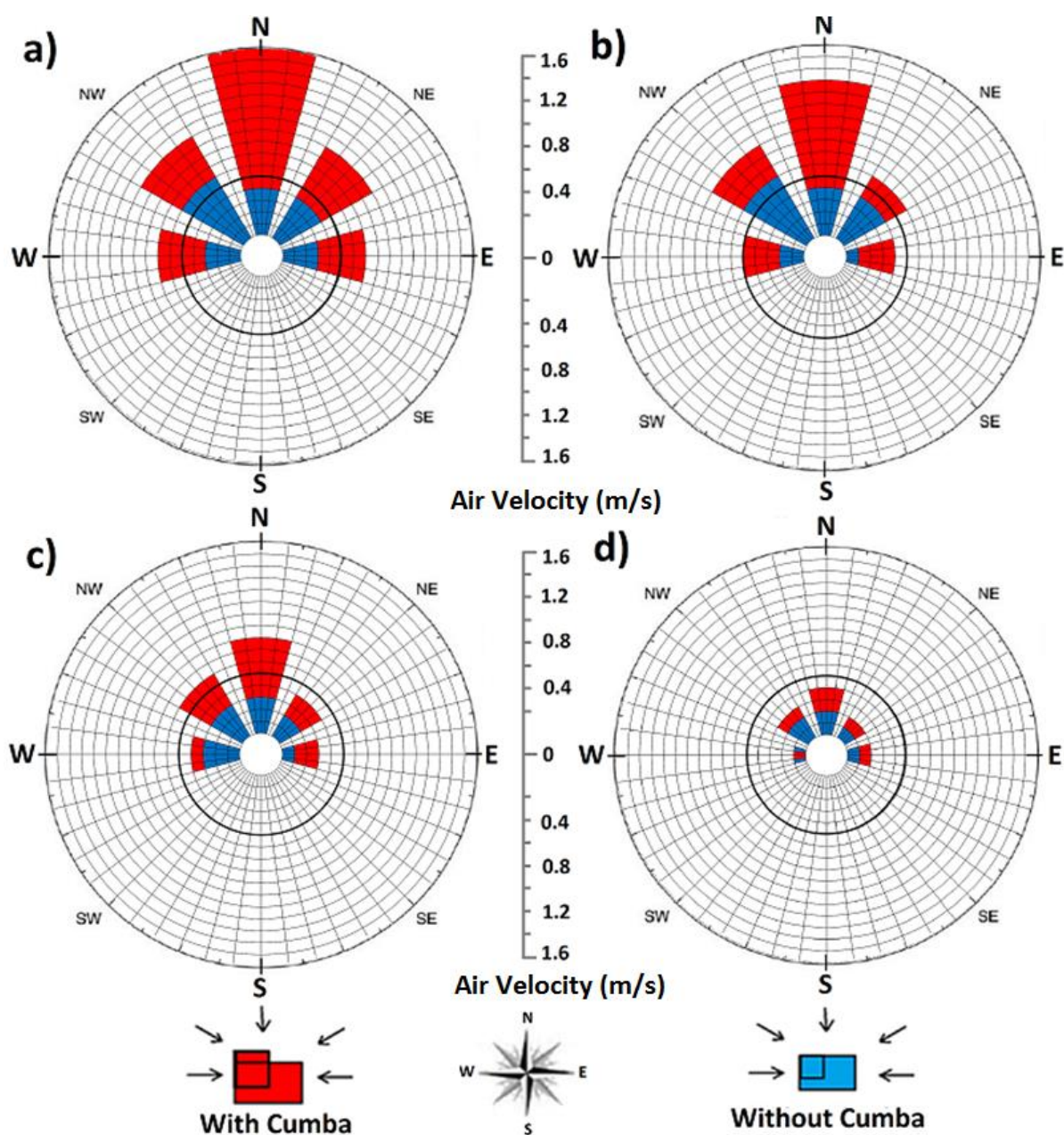

Air Velocity $(\mathrm{m} / \mathrm{s})$

d)

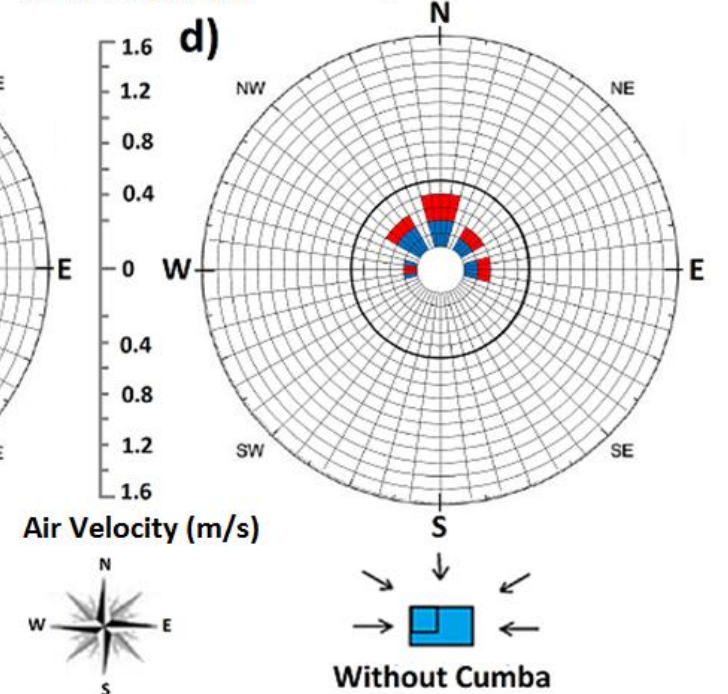

Fig. 8 Room mean air velocity (a) $5.5 \mathrm{~m} / \mathrm{s}$ (b) $4.7 \mathrm{~m} / \mathrm{s}$ (c) $3.3 \mathrm{~m} / \mathrm{s}$ (b) $1.7 \mathrm{~m} / \mathrm{s}$

Simulated interior and exterior airflow patterns and pressure distributions around the Cumba are shown in Fig. 9 and Fig. 10, respectively. In general, the existence of a Cumba significantly increases the indoor mean air velocity by $138 \%$ in scenarios S1-S20, with north-south wind velocity increasing by $223 \%$, east-west by $197 \%$, and west-east by $99 \%$. These wind directions also provide better performance in terms of mean indoor air velocity compared to the north-east (94\%) and north-west (76\%) wind directions, mainly due to the lower pressure difference between indoor and outdoor spaces in angular wind directions (north-east and north-west).

The highest mean indoor air velocity occurs in north-south wind directions (S1-S6-S11-S16) due to the advantage of air exhausted from window W6 (Fig. 9 and Fig. 11a). The mean indoor air speed reaches its peak value $(1.6 \mathrm{~m} / \mathrm{s})$ with the existence of Cumba (S16) as a consequence of the airflows passing through W6. In contrast, as illustrated in Fig. 9 and Fig. 11b, airflow exhausts in the same direction as it enters the room, and is mainly suppressed by perpendicular northward wind when a non-Cumba scenario is simulated. In north-south wind, the mean indoor air velocity does not considerably alter with increased wind velocity in room without Cumba, while it significantly changes with the existence of Cumba (Fig. 8). 


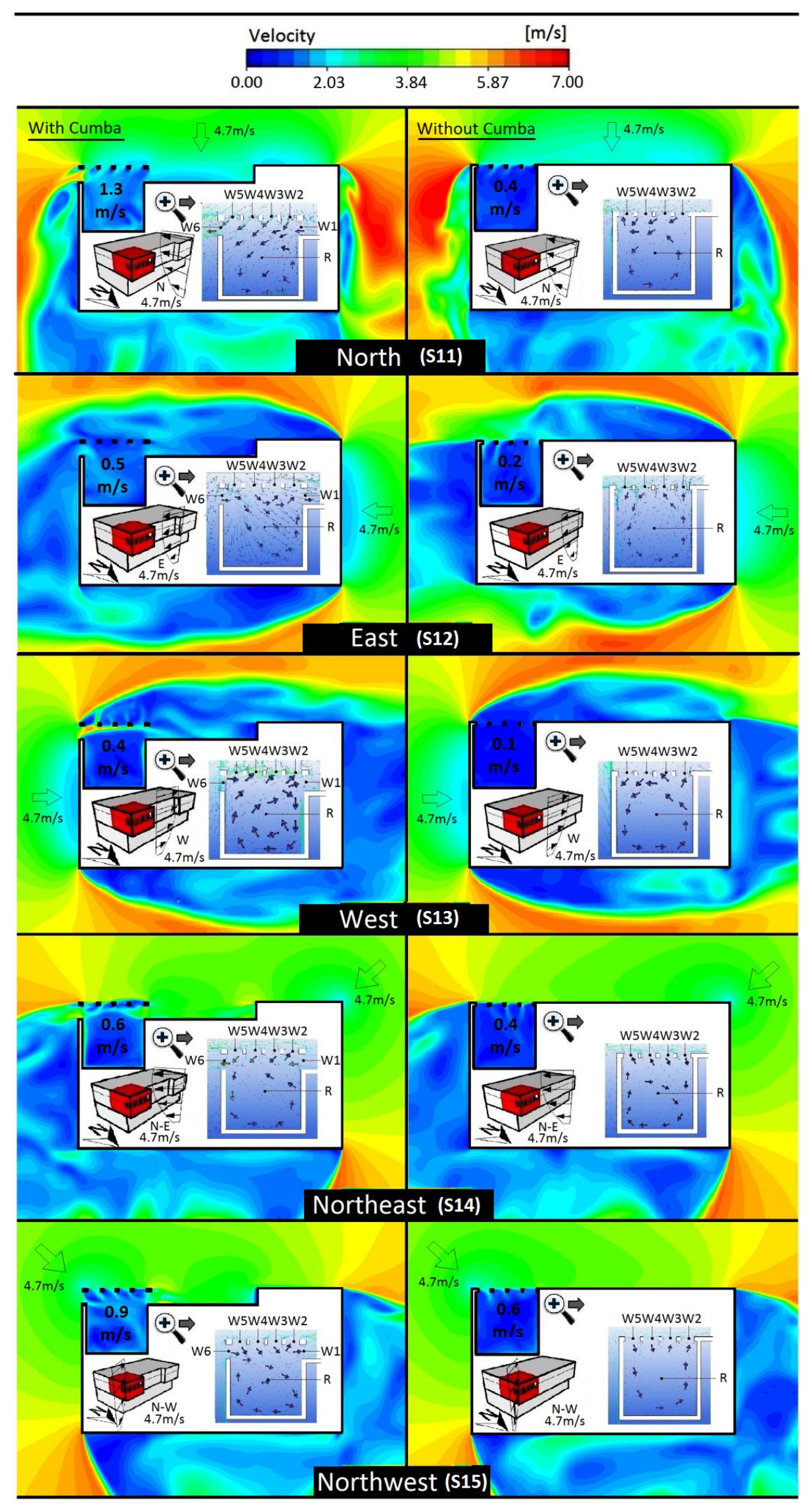

Fig. 9. Velocity contours of the scenarios with and without Cumba under different wind directions 


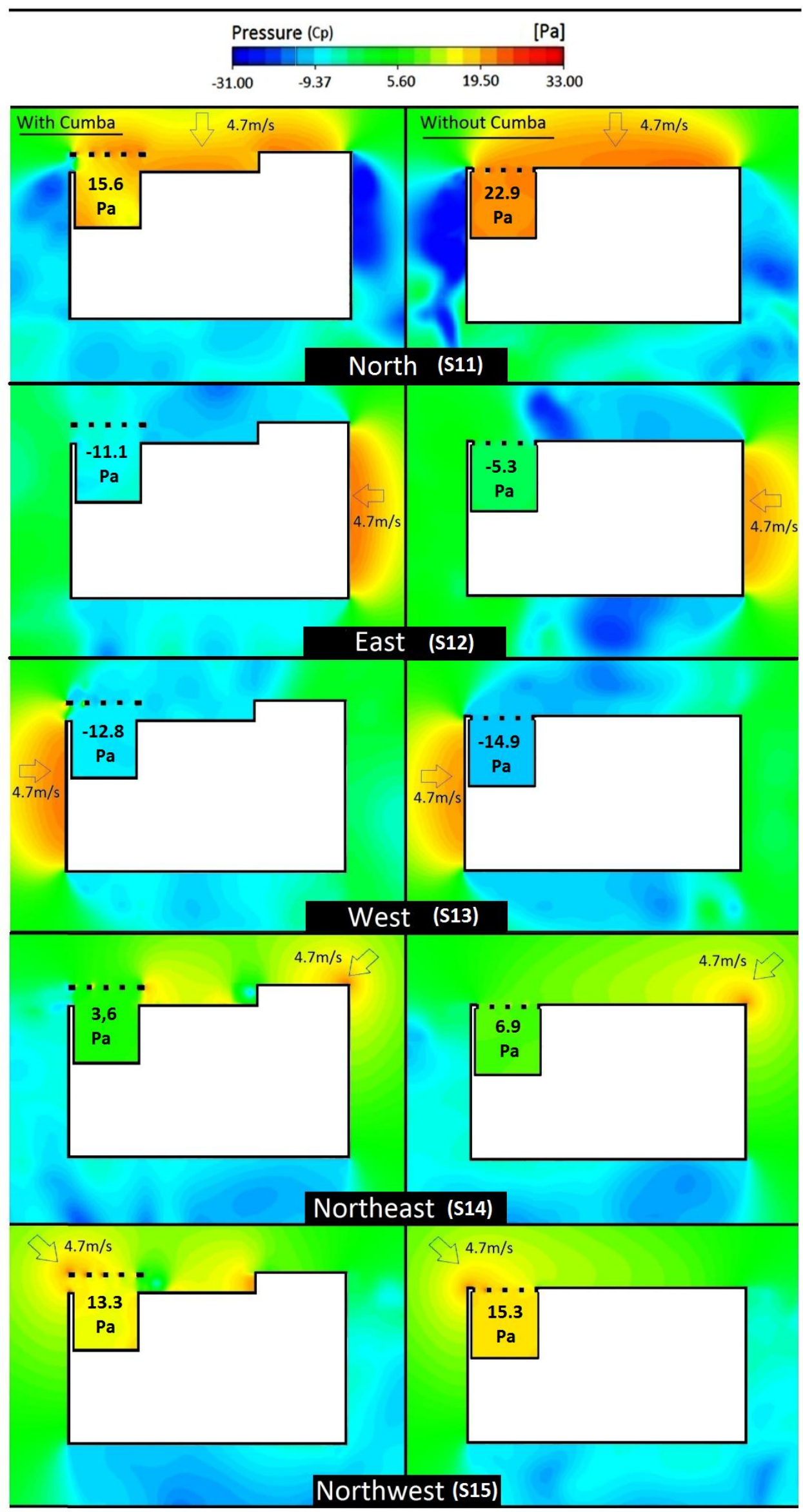

Fig.10. Pressure distribution for the scenarios with and without Cumba under different wind directions 
In the case of west-east wind, Cumba almost doubles the mean indoor air velocity (S3-S8-S13S18) as a result of the presence of window W6. The reason is again associated with a strong positive and negative pressure fields, occurring in the west and north sides of the building, respectively (Fig. 9). This means that the air enters from W6 located in high pressure zone and leaves the windows located in negative pressure zone (W1, W2, W3, W4 and W5), thereby creating a stronger circulation compared to the non-Cumba scenarios. On the contrary, for the non-Cumba scenarios (S3-S8-S13-S18), all the windows are located in the negative pressure field, thus the air enters from W5 in the vicinity of the positive pressure field and is exhausted from the rest of the windows (Fig. 9 and Fig. 11d). As a consequence, the minimum indoor pressure $(-14.9 \mathrm{~Pa})$ is observed in those scenarios (S3-S8-S13-S18) when the Cumba is not utilized (Fig. 10).

In the case of scenarios related to the eastward wind (S2-S7-S12-S17) and when Cumba is integrated to the building, W6 located in the leeward wall works as an air inlet and guide the air out through the windows W2 and W1 (Fig. 11e). On the other hand, in the non-Cumba scenarios, the airflow pattern is considerably deformed in the negative pressure field (Fig. 9 and Fig. 11f), where indoor velocity is less than half of the Cumba integrated scenario (Fig. 8). In this case, the exhausted air is more likely to return to the room, implying a potential to decrease room ventilation. This back flow, however, cannot be seen in Cumba scenario when windows W3, W4, W5, and W6 work as inlet and $\mathrm{W} 1$ and $\mathrm{W} 2$ work as outlet. As a consequence, the implementation of Cumba can provide more air exchange within the room.
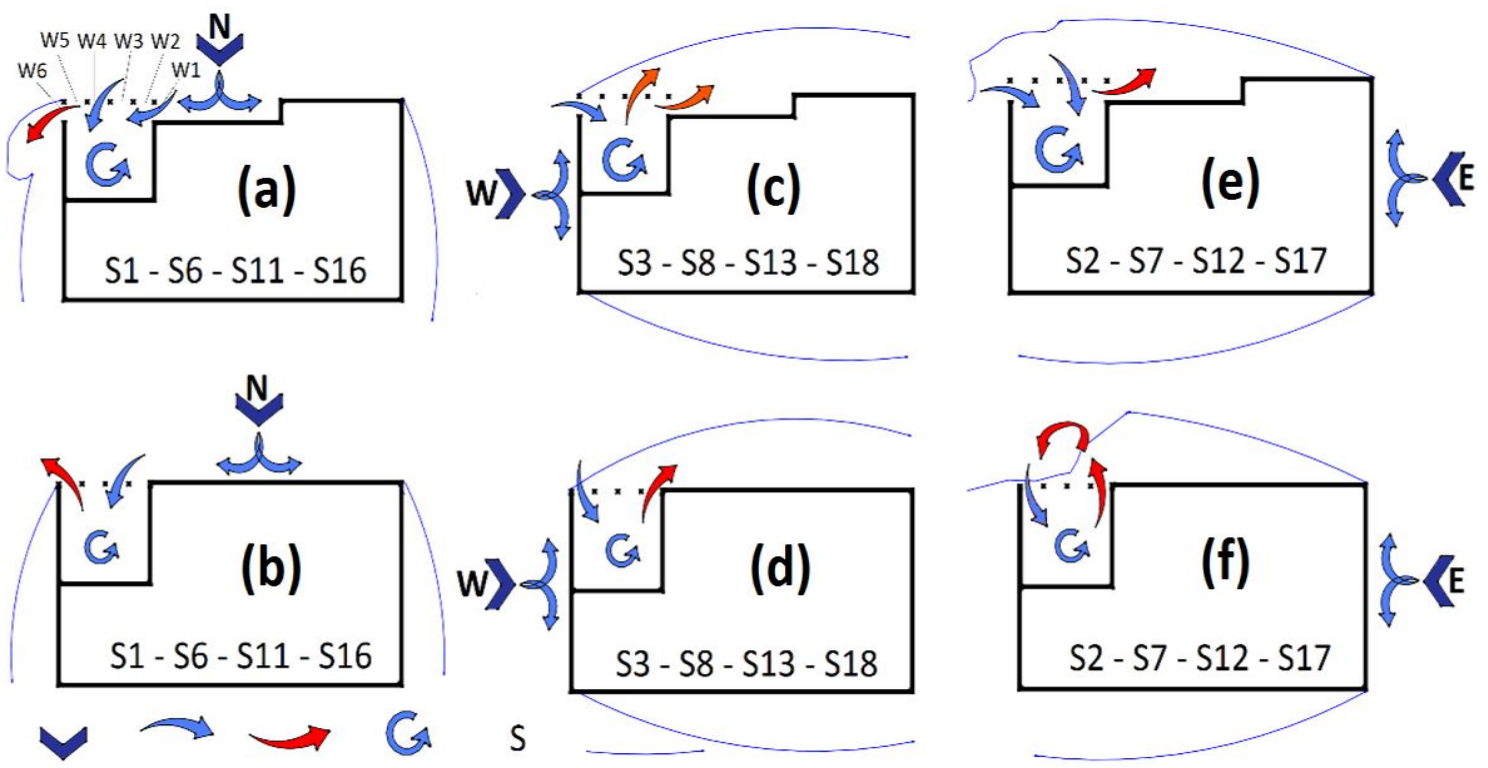

Wind Fresh Evacuated Vortex Scenarios Wind shadow

direction air air

Fig. 11 Indoor and outdoor airflow pattern of Cumba

\subsubsection{Ventilation rate}

Ventilation rate can be obtained using the following equation (Awbi, 2005):

$$
Q=C_{d} A \sqrt{\frac{2 \Delta P}{p}}
$$


where $Q$ is ventilation rate $\left(\mathrm{m}^{3} / \mathrm{s}\right), C_{d}$ is discharge coefficient (Dimensionless), $A$ is opening area $\left(\mathrm{m}^{2}\right)$, $\rho$ is air density and $\mathrm{P}$ is the difference of the external and internal pressures $(\mathrm{Pa})$.

Simulation outcomes for the ventilation rate of scenarios (S1-S20) are compared in Fig. 12. The ventilation rate was calculated with orifice equation (Eq. 1), which is broadly used in studies concerned with wind-driven ventilation rate (Chu \& Chiang, 2014; Etheridge, 2012). According to ASHRAE (2009), the minimum airflow rate necessary to ventilate the specified regular room is calculated to be $0.005 \mathrm{~m}^{3} / \mathrm{s}$ in this study, which is met in all the scenarios (S1-S20). It can be observed in Fig. 12 that the existence of Cumba significantly increases the overall ventilation rate by about $224 \%$ in all scenarios, showing its potential flexibility to harvest wind approaching from different directions and velocities.
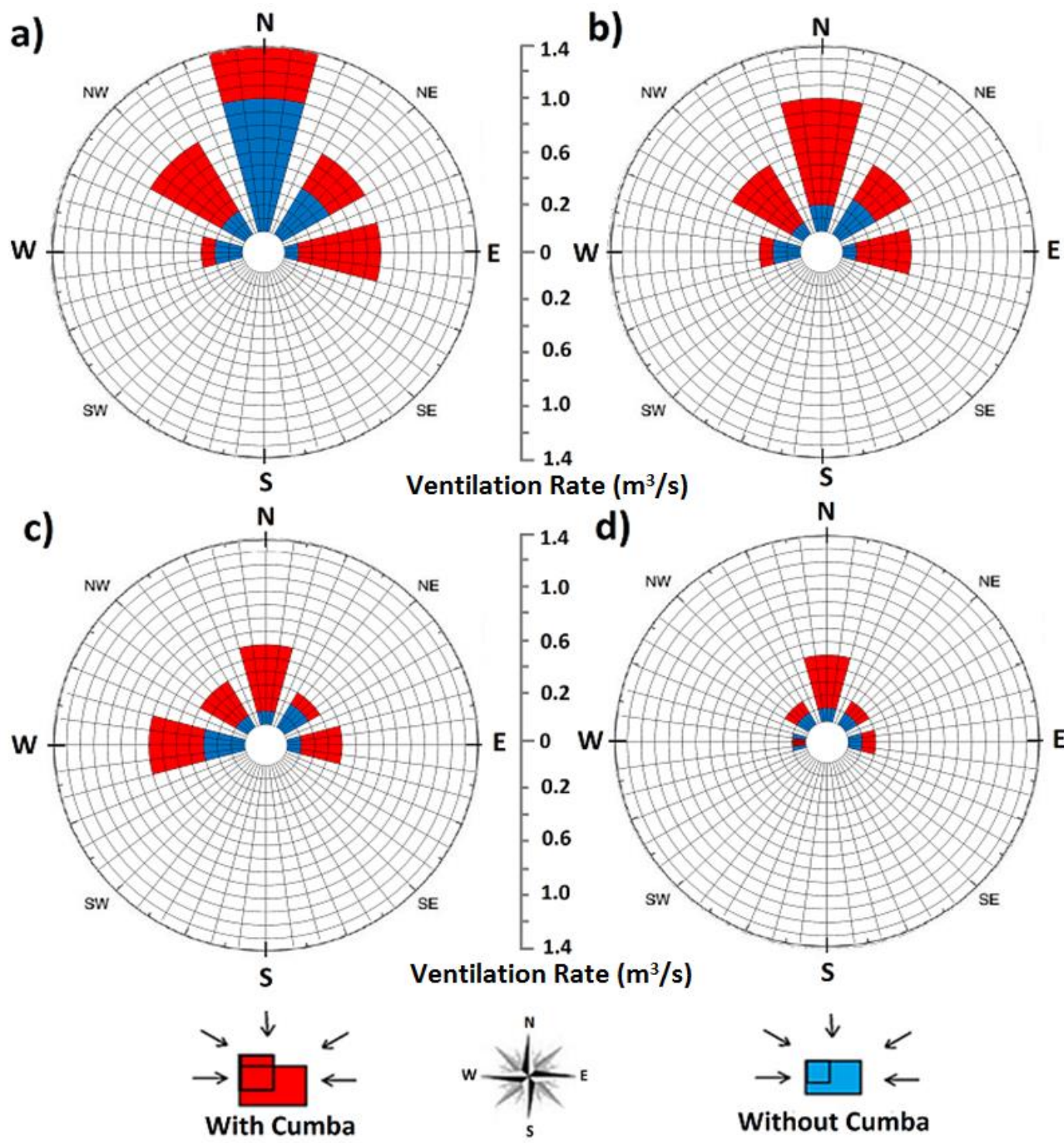

Ventilation Rate $\left(\mathrm{m}^{3} / \mathrm{s}\right)$

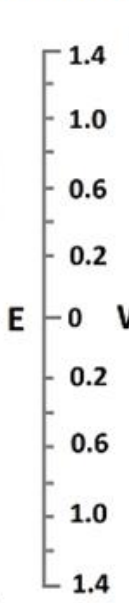

Ventilation Rate $\left(\mathrm{m}^{3} / \mathrm{s}\right)$

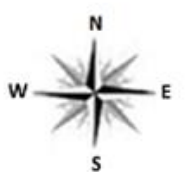

d)
N

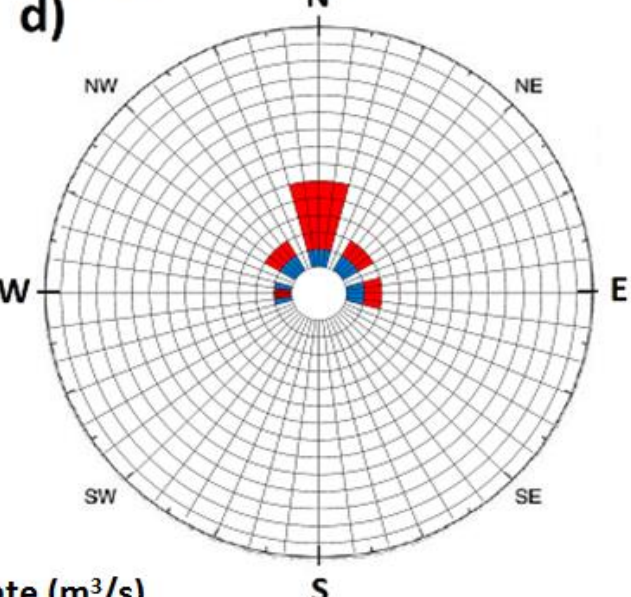

S

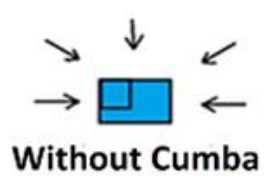

Fig. 12 Ventilation rate (a) $5.5 \mathrm{~m} / \mathrm{s}$ (b) $4.7 \mathrm{~m} / \mathrm{s}$ (c) $3.3 \mathrm{~m} / \mathrm{s}$ (b) $1.7 \mathrm{~m} / \mathrm{s}$

In two scenarios $(\mathrm{S} 16, \mathrm{~S} 8)$ the outcomes show a different pattern compared with the rest of the scenarios. Although the airflow patterns against different wind velocities are similar, they are highly deformed in scenarios $\mathrm{S} 16, \mathrm{~S} 8$. As can be seen in Fig. 12, the ventilation rate ratio against the northward wind direction is not considerably increased in the higher wind velocities in the non-Cumba scenarios. However, it is partially increased against $5.5 \mathrm{~m} / \mathrm{s}$ north-south wind in the non- Cumba 
scenario due to the existence of a formed vortex close to the window W2. Conversely, wind velocity impacts the air flow regime around $\mathrm{W} 2$ and a considerable ventilation rate increase can be observed in the associated scenarios. Similarly, a significant ventilation rate increase can be seen in scenario 58 due to the alteration of the airflow regime, whereby the air exhaust through $\mathrm{W} 1$ is relatively increased.

\section{Window opening configurations}

As depicted in Fig. 13, the impact of window opening configuration of Cumba was affected by where the Cumba was integrated in the building (S21-S24). It can be seen that the existence of a Cumba can significantly improve the mean indoor air velocity and ventilation rate. In comparison to S11, the minimum mean air velocity and ventilation rate difference of about $23 \%$ and $35 \%$ can be calculated when W6 is set to be closed (S25). On the other hand, the maximum mean air velocity difference is observed between scenarios S11, S21 and S23, where mean air velocity in scenarios S11 and S21 are almost equal. A maximum ventilation rate difference of about $580 \%$ was obtained between scenarios S11 and S22.

In particular, by extending the building façade, the Cumba creates a significant pressure difference in $\$ 22$ scenario, which improves the overall air exchange rate. The mean air velocity and ventilation rate are elevated by about $38 \%$ and $580 \%$ in comparison to 511 , when a Cumba is not integrated to the building, although they both have a similar number of windows. This clearly indicates that the enhanced wind-driven ventilation by Cumba is not only associated with windows' orientation, but their opening configuration can also help to control and adjust different required ventilation rates. For example, the currently designed Cumba can provide mean indoor air velocity of 0.5 to $1.3 \mathrm{~m} / \mathrm{s}$ and ventilation rate of $0.3 \mathrm{~m}^{3} / \mathrm{s}$ to $1.4 \mathrm{~m}^{3} / \mathrm{s}$ with different opening configurations (Fig. 13).

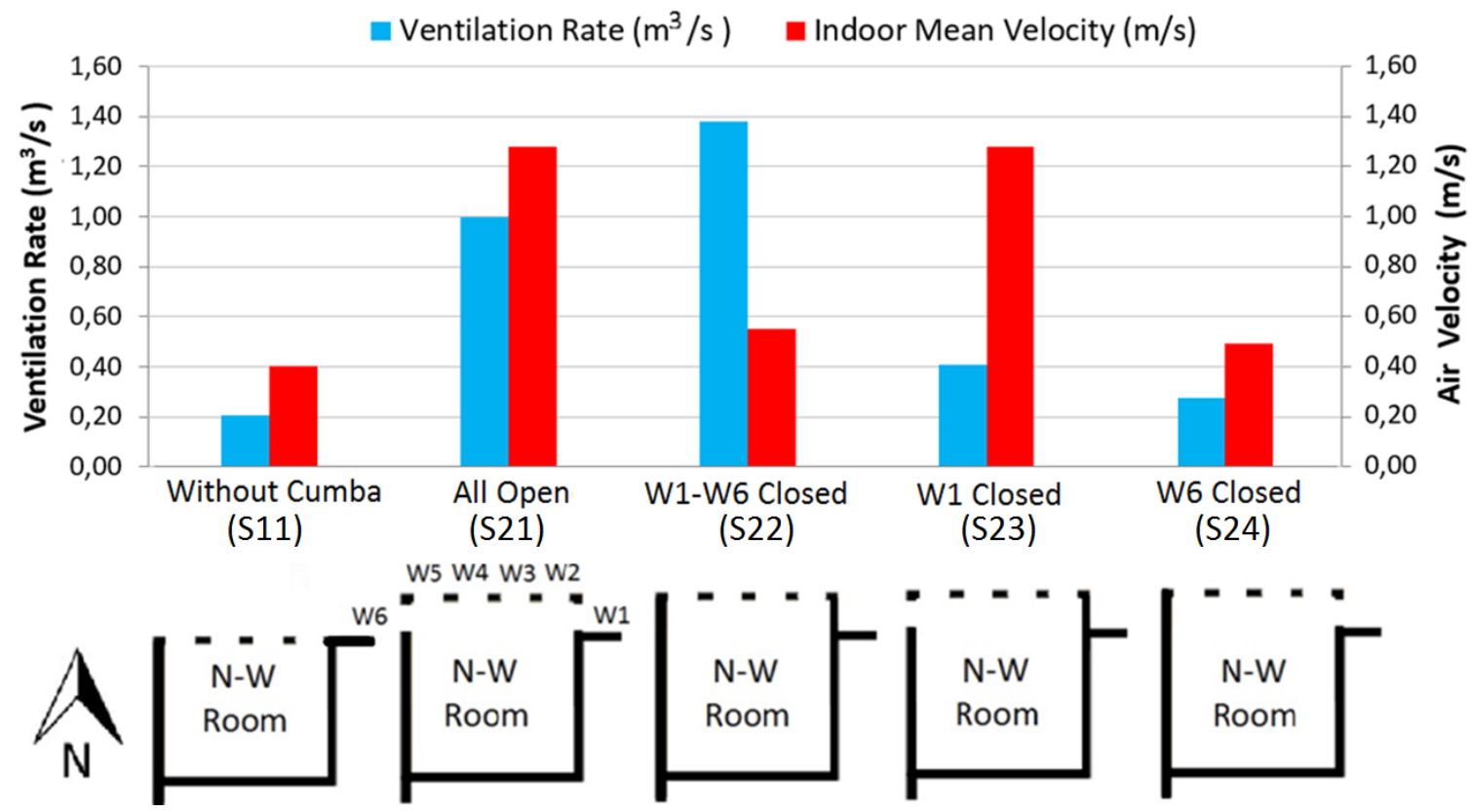

Fig. 13. Comparison of room mean air velocity and ventilation rate according to different window opening configurations 


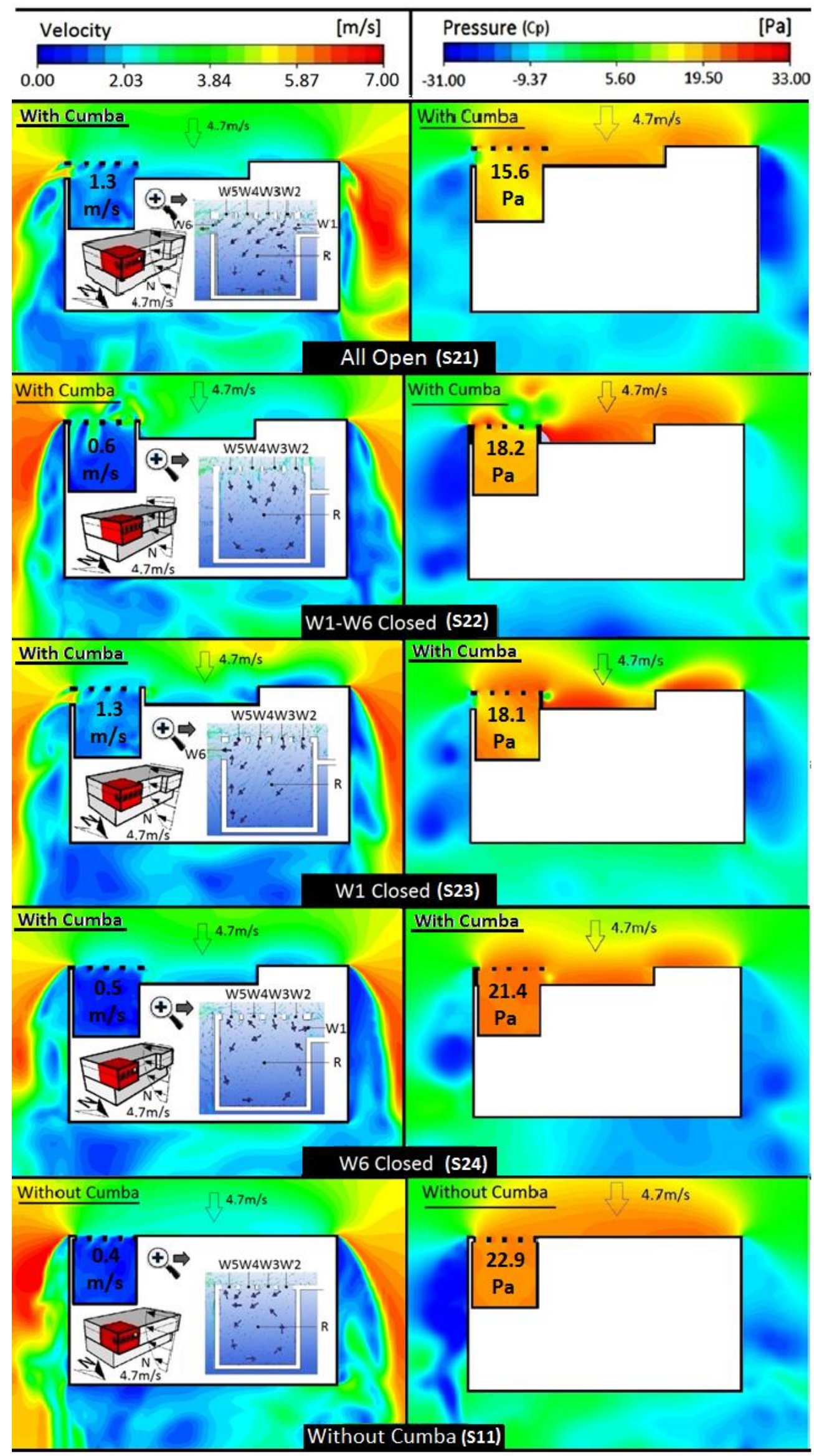

Fig. 14. Velocity contours and pressure distribution for different window opening configurations 


\section{Conclusion}

Wind-driven ventilation of the Cumba traditional Turkish architectural element was investigated with a series of microclimate CFD simulations. The microclimate CFD model was firstly validated with a similar study by Bangalee (2012). A case study building was then selected as a result of a comprehensive survey over 111 existing traditional Turkish buildings. The most common plan typology was identified as a house layout with four rooms, internal Sofa, and two Cumbas. A threesided Cumba was found to be the most popular type. The smallest room varied between $11-20 \mathrm{~m}^{2}$, while the main room area was between $21-30 \mathrm{~m}^{2}$. Also, the width of windows mainly varied from $0.6 \mathrm{~m}$ to $1 \mathrm{~m}$.

In general, Cumba is an effective strategy in harvesting wind approaching from different directions. Mean indoor air velocity and ventilation rate were utilized as key indices to evaluate the wind-driven ventilation of the selected benchmark building. Various scenarios were investigated by the alteration of parameters such as wind direction, wind velocity and window opening configuration. In general, three-sided Cumba demonstrated the most promising performance to harvest approaching winds. The Cumba could enhance the room's mean air velocity and ventilation rate under different climatic conditions by about 1.4 and 2.2 times, respectively. Moreover, Cumba window opening configurations provides ventilation flexibility as the room's mean air velocity and ventilation rate can be adjusted to a broad range of values, e.g. example, mean indoor air velocity of 0.5 to $1.3 \mathrm{~m} / \mathrm{s}$ and ventilation rate of $0.3 \mathrm{~m}^{3} / \mathrm{s}$ to $1.4 \mathrm{~m}^{3} / \mathrm{s}$ with different opening configurations is achieved in this study.

Further investigation with the original building layout with all rooms and without any modification is needed to assess the wind-driven ventilation enhancement of Cumba and the influence on other room's natural ventilation. Moreover, different Cumba typologies such as two- and particularly four-sided Cumba can be studied to have a deeper understanding about the Cumba's working mechanism. Considering other physical properties, the Cumba also has considerable potential to provide natural lighting.

\section{References}

Ai, Z., \& Mak, C. (2014). A study of interunit dispersion around multistory buildings with single-sided ventilation under different wind directions. Atmospheric Environment, 1-13.

Arseven, C. (1983). Sanat ansiklopedisi, 5th ed. Istanbul: Milli egitim bakanlıgı.

ASHRAE (2009). The ASHRAE Guide for Buildings in Hot \& Hummid Climates Second Ed. Atlanta: ASHRAE.

Awbi, H. B. (2005). Ventilation of Buildings, 2nd ed. New York: Taylor \& Francis.

Bangalee, M., Lin, S., \& Miau, J. (2012). Wind driven natural ventilation through multiple windows of a building: A computational approach. Energy and Buildings, 317-325.

Cantin, R., Burgholzer, J., Guarracino, G., Moujalled, B., Tamelikecht, S., \& Royet, B. (2010). Field assessment of thermal behaviour of historical dwellings in France. Building and Environment, 473-484.

Chu, C., \& Chiang, B. (2013). Wind-driven cross ventilation with internal obstacles. Energy and Buildings, 201-209.

Chu, C.-R., \& Chiang, B.-F. (2014). Wind-driven cross ventilation in long buildings. Building and Environment, 150-158.

Dili, A., Naseer, M., \& Varghese, T. Z. (2011). Passive control methods for a comfortable indoor environment: Comparative investigation of traditional and modern architecture of Kerala in summer. Energy and Buildings, 653-664. 
ECOTECT. (2016, 01 29). Naturalfrequency. ECOTECT: http://wiki.naturalfrequency.com/wiki/Air_Movement adresinden alındı

Eldem, S. H. (1984). Turkish houses ottoman period. Turkey: Türkiye anıt cevre turizm değerlerini koruma vakfı(T.A.C).

Essad, D. (1909). Constantinople_De Byzance à Stamboul . Paris: Librarie Renouard H. Laurens.

Etheridge, D. (2012). Natural ventilation of buildings: theory and measurement and design. Chichester, England: John Wiley and Sons.

Evola, G., \& Popov, V. (2006). Computational analysis of wind driven natural ventilation in buildings. Energy and Buildings, 491-501.

Franke, J., Hellsten, A., Schlünzen, H., \& Carissimo, B. (2007). Best practice guideline for the CFD simulation of flows in the urban environment. Brussels: Cost Office.

Gebremedhin, K., \& Wu, B. (2003). Characterization of flow field in a ventilated space and simulation of heat exchange between cows and their environment. Journal of Thermal Biology, 301-319.

Günay, R. (1998). Türk ev gelenegi ve Safranbolu evleri. Istanbul: Yapı endüstri merkezi (YEM).

Heiselberg, P., Svidt, K., \& Nielsen, P. V. (2001). Characteristics of air\$ow from open windows. Building and Environment, 859-869.

Horan, J., \& Finn, D. (2008). Sensitivity of air change rates in a naturally ventilated atrium space subject to variations in external wind speed and direction. Energy and Buildings, 1577-1585.

IPPC/CC. (2014). Climate Change 2014 Synthesis report Summary for polcymakes Report of the Intergovermental Panel on Climate Change. IPPC.

IUG-MI. (2015, 11 1). Istanbul universitesi fen fakultesi, astronomi ve uzay bilimleri bolumu. Istanbul universitesi gozlemevi metroroloji istasyonu: http://astronomi.istanbul.edu.tr/meteor/ adresinden alındı

Kobayashi, T., Sandberg, M., Kotani, H., \& Claesson, L. (2010). Experimental investigation and CFD analysis of crossventilated flow through single room detached house model. Building and Environment, 2723-2734.

Küçükerman, Ö. (2007). Turkish house in search of spatial identity. Turkey: Türkiye Turing ve Otomobil Kurumu.

Lai, H., Kendall, M., Ferrier, H., Lindup, I., Alm, S., Hanninen, O., . . Nieuwenhuijsen, M. (2004). Personal exposures and microenvironment concentrations of PM2.5, VOC, NO2 and CO in Oxford, UK. Atmospheric Environment, 63996410.

Lee, J., Jung, H., Park, J., Lee, J., \& Yoon, Y. (2013). Optimization of building window system in Asian regions by analyzing solar heat gain and daylighting elements. Renewable Energy, 522-531.

McQuiston, F. C., Parker, J. D., \& Spitler, J. D. (2005). Heating, Ventilating and Air Conditioning Analysis and Design; 6 edition. USA: John Wiley \& Sons, Inc.

Mirzaei, P. .., \& Haghighat, F. (2010). A novel approach to enhance outdoor air quality: Pedestrian ventilation system. Building and Environment, 1582-1593.

Mirzaei, P. A., \& Carmeliet, J. (2013). Dynamical computational fluid dynamics modeling of the stochastic wind for application of urban studies. Building and Environment, 161-170.

Mirzaei, P. A., \& Haghighat, F. (2010). Approaches to study Urban Heat Island - Abilities and limitations. Building and Environment, 2192-2201.

Mirzaei, P. A., Haghighat, F., Nakhaie, A. A., Yagouti, A., Giguère, M., Keusseyan, R., \& Coman, A. (2012). Indoor thermal condition in urban heat Island - Development of a predictive tool. Building and Environment, 7-17. 
Mochida, A., Yoshino, H., Miyauchi, S., \& Mitamura, T. (2006). Total analysis of cooling effects of cross-ventilation affected by microclimate around a building. Solar Energy, 371-382.

Mochida, Y. T., Yoshie, R., Kataoka, H., Nozu, T., Yoshikawa, M., \& Shirasawa, T. (2008). AlJ guidelines for practical applications of CFD to. Wind engineering and industrial aerodynemics, 1749-1761.

NASA/GCC. (2016, 1 1). NASA Global Climate Change Cital Signs of the Planet. NASA/GCC: http://climate.nasa.gov/vitalsigns/global-temperature/ adresinden alındı

Norton, T., Grant, J., Fallon, R., \& Sun, D.-W. (2009). Assessing the ventilation effectiveness of naturally ventilated livestock buildings under wind dominated conditions using computational fluid dynamics. Biosystems engineering, 78-99.

Perén, J., Hooff, T. v., Leite, B., \& Blocken, B. (2015). CFD analysis of cross-ventilation of a generic isolated building with asymmetric opening positions: Impact of roof angle and opening location. Building and Environment, 263-276.

Saadatian, O., Haw, L. C., Sopian, K., \& Sulaiman, M. (2012). Review of windcatcher technologies. Renewable and Sustainable Energy Reviews, 1477-1495.

Samuel, D. L., \& Nagendra, S. S. ( 2013). Passive alternatives to mechanical air conditioning of building: A review. Building and Environment, 54-64.

Talya, H. (2007). Gelenksel Turk mimarisinde yapı sistem ve elemanları. Istanbul: Turkiye Anıt Cevre Turizm Degerlerini Koruma Vakfı (TAC).

Teppner, R., Langensteiner, B., Meile, W., Brenn, G., \& Kerschbaumer, S. (2014). Air change rates driven by the flow around and through a buildingstorey with fully open or tilted windows: An experimental andnumerical study. Energy and Buildings, 640-653.

Torfs, R., Brouwere, K. D., Spruyt, M., Goelen, E., Nickmilder, M., \& Bernard, A. (2008). Exposure and risk assessment of air fresheners. VITO, Document No 2008/IMS/R/222.

Vardoulakis, S., Dimitroulopoulou, C., Thornes, J., Lai, K.-M., Taylor, J., Myers, I., Wilkinson, P. (2015). Impact of climate change on the domestic indoor environment and associated health risks in the UK. Environment International, 299-313.

WB. (2016, 1 1). Weatherbase. http://www.weatherbase.com/ adresinden alındı

WEC/WERS. (2013). World Energy Council World Energy Resources 2013 Survey Summary. London: World energy Council.

WEC/WES-2050, W. E. (2013). World Energy Council World Energy Scenarios Composing energy futures to 2050. London: World Energy Council.

Wilhelmi, O. V., Purvis, K. L., \& Harriss, R. C. (2004). Designing a Geospatial Information Infrastructure for Mitigation of Heat Wave Hazards in Urban Areas. Natural Hazards Review, 147-158. 